e-ISSN: 2721-3013, p-ISSN: 2721-3005

DOI: https://doi.org/10.38035/jafm.v1i4

Received: 3 Agust 2020, Revised: 16 Agust 2020, Publish: 2 September 2020 https://creativecommons.org/licenses/by/4.0/

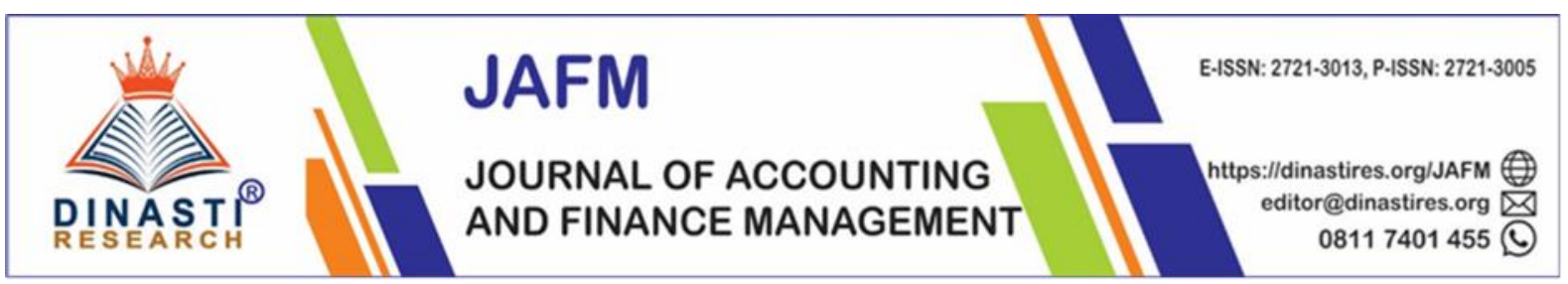

\title{
Building Employee Performance Based on Compensation and Work Training With Variables of Work Satisfaction (Performance Analysis of PT. Harapan Abadi Employees)
}

\author{
Muhammad Irfan Rahadian ${ }^{*}$, I Ketut R Sudiarditha ${ }^{2}$, Ari Saptono ${ }^{3}$ \\ ${ }^{1), 2), 3)}$ Magister Management student at Jakarta State University,email: mirfanrhdn007@gmail.com \\ *Corresponding author: Muhammad Irfan Rahadian ${ }^{1}$
}

\begin{abstract}
This study aims to analyze compensation and training on employee performance through satisfaction variables. This research uses a quantitative method using the SEM Lisrel 8.8 Program analysis tool. The number of respondents was 105 employees of PT. Sumber Harapan Abadi (DataPrint). The sampling technique in this study was purposive nonprobability sampling using the Isaac and Michael method approach. The novelty in this study is the positive effect of compensation and job training on employee performance through employee job satisfaction. The results of the study stated: 1) there was a positive and significant effect of compensation on job satisfaction. 2) there is a significant positive effect of training on job satisfaction 3) there is a positive and significant effect of the effect of compensation on performance. 4) a positive and significant effect of training on performance. 5) there is a positive and significant effect of job satisfaction on performance 6) there is a positive and significant effect of training on performance. 7) the positive and significant influence of the effect of training on performance through job satisfaction.
\end{abstract}

Keywords: Compensation, Satisfaction, Performance, Training

\section{INTRODUCTION}

Human resources (HR) is a central factor in a company organization. Whatever the shape and purpose, the organization is made based on various visions for the benefit of humans and in the implementation of its mission is managed and managed by humans. So, humans are a strategic factor in all institutional or organizational activities. Furthermore, these human resources must be regulated and managed based on the organization's vision so that organizational goals can be achieved optimally.

The era of free trade in the 21 st century is a climate of high competition in all fields which requires companies to work more effectively and efficiently. High level of competition also requires an organization to optimize its human resources, this is due to the strong influence of human resources on the effectiveness and efficiency of the organization, employees as human resources are the key to organizational success. Human resource 
management in the organization, there will always be several problems that affect the effectiveness and efficiency of the performance of employees such as; employ employees who are not in line with work demands, experience high employee turnover, employees do not make the best work contribution or are less motivated, employee discrimination, unsafe work environment conditions or violate work safety laws, injustice in giving salaries, promotions, workforce practices, lack of training and employee development. In addition, many factors affect employee performance in producing a productivity in the company. This problem is a problem that becomes a problem for companies in developing companies in this era of very tight competition as experienced by Data Print

Facing competition like now PT. Sumber Harapan Abadi continues to invest in human resources by recruiting, selecting and maintaining human resources. This is done to get quality human resources owned by PT. Sumber Harapan Abadi where this aspect is a crucial aspect in an organization. As for the phenomena in the research as contained in Figure 1.1 below:

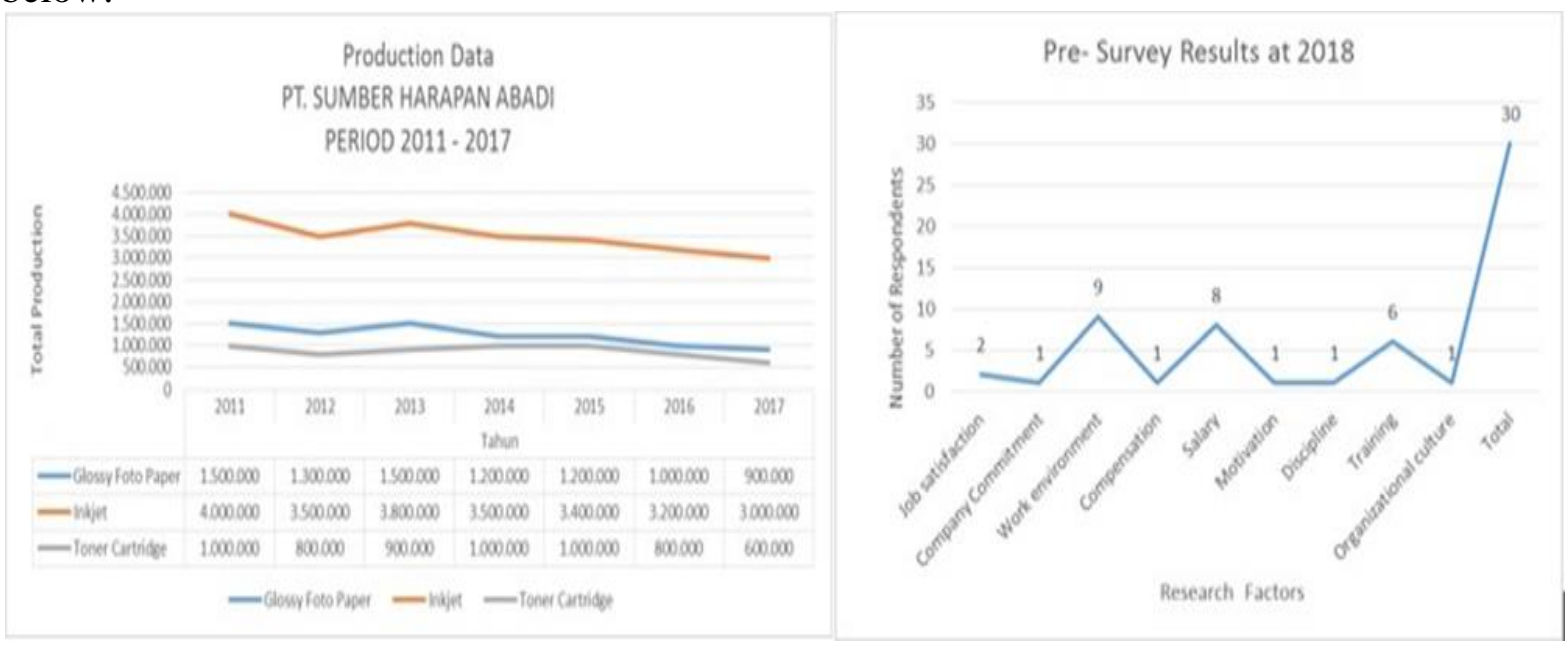

Ficture 1. Production Data and Research Factor Pre-Survey Results

Source: HR Department of PT. Sumber Harapan Abadi (2019)

In Figure 1. above, it shows that in the 2017 period the total production produced was significantly decreased significantly in line with the increase in employee turnover at PT. Sumber Harapan Abadi. This phenomenon attracts attention to examine the causes of the turnover and decline in production at PT. Sumber Harapan Abadi. To answer this phenomenon, the researchers conducted a preliminary study or pre-survey of what factors affect employee performance so that it affects employee performance which can be seen from the decreased production results.

Researchers in conducting a pre-survey, distributed 30 questionnaires to PT. Sumber Harapan Abadi production employees who had worked for at least 1 year of work and had become permanent employees. This pre-survey was conducted by researchers by direct interviews with employees in the form of open-ended questions. Factors that influence employee performance show that the statements most frequently made by employees to improve employee performance are factors of job satisfaction, compensation, salary, and training. Based on the results of the pre-survey conducted by researchers, then for further research researchers are interested in analyzing the relationship between compensation, and training as an independent factor, job satisfaction as a mediator factor and employee performance factors as a dependent factor. Analysis of this research has been done by many other researchers which can be seen in previous studies that researchers included as a basis for this research. 
In analyzing the effect of compensation, job training, job satisfaction on performance, many researchers have done it before. A total of 15 researchers have analyzed the effect of compensation, training and satisfaction on performance with the results of the analysis that compensation, training and job satisfaction partially affect employee performance.

Based on the background above, the main questions to be analyzed are the effect of compensation on job satisfaction, the effect of training on job satisfaction, the effect of compensation on work performance, the effect of training on employee performance, the effect of job satisfaction on employee performance, the effect of compensation on performance employees through job satisfaction and the effect of training on employee performance through job satisfaction

This research was conducted with the aim to provide an answer to the problems faced by the company by analyzing the influence of variables such as the effect of compensation on job satisfaction, the effect of training on job satisfaction, the effect of compensation on work performance, the effect of training on employee performance, the effect of job satisfaction on performance employees, the effect of compensation on employee performance through job satisfaction and the effect of training on employee performance through job satisfaction.

This research is expected to have the following benefits: 1.Theoretical Benefits. This research is expected to broaden knowledge on science, especially in the field of human resource development regarding compensation, training, job satisfaction and performance.

From the practical aspects of the use of this study to determine the effect of compensation on job satisfaction, the effect of training on job satisfaction, the effect of compensation on performance, the effect of training on performance, the effect of job satisfaction on performance, the effect of compensation on performance through job satisfaction, the effect of training on performance through job satisfaction.

\section{LITERATURE REVIEW Performance}

Performance Is the answer to the success or failure of the goals set by an organization. Managers often do not pay attention to this performance, unless, there has been a result of a very bad performance. Performance can be said to be good if the results are good, for example in increasing sales in a company, the more sales are sold, the better the performance.

Noe.et.al. (2015: 536) defines Performance is the result of work in which both the quality and quantity achieved by an employee in carrying out their duties in accordance with the responsibilities given to him. Meanwhile, according to Priyono (2010: 185) work performance is the result achieved by someone according to the applicable measures of the work in question. Furthermore Priyono (2010: 185) argues that work performance or performance is the result of one's work over a certain period compared to various possibilities, such as standards, targets / targets or criteria that have been determined in advance and have been mutually agreed upon. While Kurniawan, (2005: 46) defines that employee performance (work performance) is the work achieved by an employee from the results of carrying out their duties both in quality and quantity in accordance with the responsibilities they bear. "So that Performance is an assessment of the quality of implementation of the tasks or operations of an organization, (Mangkunegara, 2011: 9). Potale and Uhing (2015: 65) in their research results provide conclusions on the notion of performance, namely the quality and quantity of work achieved by an employee in carrying out their duties in accordance with the responsibilities given to him. Employee performance is a measurement of the results of handling work that can be done by employees which are measured in terms of quality and quantity. Measures from a quality perspective show the results of work are based on standards set by the company, and the size of the quantity is based on the level of completion or the number of units resulting from the work done by 
employees. As'ad (2010: 57) provides a limitation that work performance as someone's success in carrying out work or "successful role achievement" which a person gets from his own actions. This means that job performance is the result achieved by someone according to the applicable measures of the work in question (Priyono, 2010: 185).

From the description of the experts, the performance can be synthesized as a result of work achieved by an employee or group of employees within the time specified as executing their duties in accordance with the field that is the responsibility of each individual employee by paying attention to both quality and quantity.

\section{Job Satisfaction}

Over time, to improve employee productivity, managers and company leaders must be able to understand the notion of job satisfaction. Job satisfaction will be achieved if in managing human resources the managers and company leaders understand well what is called job satisfaction itself. Meeting employee job satisfaction is one of the determinants of increasing employee work productivity.

According to Robbins (2015: 170) job satisfaction is a general attitude towards one's work as the difference between the amount of rewards received by workers and the amount of rewards believed to be received. Job satisfaction or job satisfaction identical with things that are individual. Therefore, the level of satisfaction of each person is different and what happens if several factors are met, namely individual needs and their relationship with the degree of employee preference and dislike. Ricahard, Robert and Gordon (2012: 312,337) assert that job satisfaction is related to one's feelings or attitudes about the job itself, salary, promotion or education opportunities, supervision, work colleagues, workloads and others. He continued the statement that job satisfaction is related to one's attitude about work, and there are several practical reasons that make job satisfaction an important concept for leaders. Dissatisfied workers tend to be resistant in relation to leadership and engage in counterproductive behaviors.

Meanwhile, according to Priansa (2014: 291) job satisfaction is an employee's feelings about his work, whether happy / like or not / disliked as a result of employee interaction with the work environment or as a perception of mental attitude, also as a result of employee assessment of his work. Employees' feelings about their jobs reflect their attitudes and behavior at work. The Wilson Bangun $(2012$; 327) defines job satisfaction, namely job satisfaction of an employee can feel the work whether it is fun or not pleasant to do.

As explained by the experts above, job satisfaction can be synthesized as a general attitude towards work and to the compensation felt by each individual employee.

\section{Compensation}

Organizationalusually has a very complex compensation problem, but it is important for employees and the organization itself (Sedarmayanti, 2010: 239). Furthermore, compensation can also mean all income in the form of money, direct or indirect goods received by employees in return for services rendered to the company. The establishment of effective compensation systems is an important part of human resource management because it helps attract and retain talented jobs. In addition the company's compensation system has an impact on strategic performance. (Hasibuan 2017: 119)

Handoko (2014: 155) defines compensation as everything that employees receive as compensation for their work. Compensation programs are also important for companies, because they reflect the organization's efforts to maintain human resources. Whereas Wibowo (2016: 271) defines that compensation is a number of packages offered by the organization to workers in return for the use of its workforce. 
From the description of the experts above, compensation can be synthesized as an income received by each individual employee in the form of money, awards, goods in return for services provided by each individual employee of the company.

\section{Training}

Training is part of education to improve skills outside the formal education system or education, which is carried out in a short time and prioritizes practice rather than theory (Priyono and Marnis, 2010: 101). While Andrew E. Sikula was quoted by Sedarmayanti (2011: 44) stating, a short-term educational process that uses systematic and organized procedures in which non- managerial employees learn technical knowledge and skills in limited goals. Another description from Gary Dessler (2011: 89) argues that training, that is, provides the skills needed for new employees or existing employees to carry out their work.

According to Moekijat (1991), quoted by Priyono and Marnis (2011: 102) explains that there are three conditions that must be met in training, such as training must help employees increase their abilities ,. Exercise must cause changes in the employee's work habits, in his attitude towards work, in the information and knowledge he applies in his daily work, exercise must be related to a particular job. Employees can take part in various educational programs that are not called training, because the relationship with his current job or with specific tasks for which he might be appointed in the future is little or no. According to Veithzal rivai (2010: 225-226), there are several factors that can affect training, namely instructors, participants, material (materials), methods, training objectives, and the supporting environment.

Ernest J. Mccormick (Mangkunegara, 2011: 46) explained that an organization needs to involve its employees or employees in training activities if it is the best decision of the manager. The results of the training are expected to achieve other results than modifying employee behavior. It also needs organizational support and goals, such as more efficient production, distribution of goods and services, emphasizing operating costs, improving quality and more effective personal relationships. Goldstein and Bukton cited by Anwar Prabu Mangkunegara (2011: 46) stated that there were three training needs analyzes namely organizational analysis, job and task analysis, and employee analysis. Veithzal Rivai and Ella Jauvani Sagala (2010: 217) divide the benefits of training, namely the benefits for the company and for individuals where the ultimate goal is to achieve the vision, mission, company goals, and human relations and the implementation of company policies.

From the description of the experts above the training can be synthesized as education with the aim to improve the skills and abilities of employees in achieving the company's vision and mission.

\section{Conceptual framework}

\section{Effects of Compensation Towards Job Satisfaction}

According to Sitania.et.al (2018) there is a significant and positive influence of the compensation variable (X1) on the mediator variable of job satisfaction. This influence is built by the relationship between dimensions of compensation variables according to payment, performance, comparable, appropriate, risk, length of work, on time with dimensions of job satisfaction variables such as the work itself, salary / salary, promotion, supervision, Co-workers. Sanaz Vatankhah, (2017), argues that there is a significant and positive effect of the independent compensation variable on job satisfaction mediator variables. This influence is built by the relationship between dimensions of the compensation variable such as direct financial compensation, and indirect compensation with the satisfaction variable dimension work such as the work itself, salary / wages, promotion, supervision, coworkers. Compensation has a significant and positive effect on job 
satisfaction. This influence is built by the relationship between dimensions of compensation variables such as direct compensation and indirect compensation with dimensions of job satisfaction such as Work itself, Salary / Wages, Promotion, Supervision, Colleagues (Bryant. Phil C, 2013). According to Rubel.et.al, (2015), in one of the analyzes found that there was a significant and positive influence of the independent variable compensation on the mediator variable of job satisfaction. This influence is built by the relationship between the dimensions of the variable compensation compensation, benefits with variable dimensions of job satisfaction such as the job itself, salary / wages, promotion, supervision (supervision), coworkers.

From the results of the analysis conducted by Sitania.et.al (2018), Vatankhah, et.al (2017), Bryant, et.al (2013), Rubel.et.al (2015), although using their respective approaches it can be concluded that the influence of the independent compensation

variable on the job satisfaction dependent variable and the performance dependent variable. Henceforth researchers will use an approach from the results of research Sitania.et.al (2018), Vatankhah, et.al (2017) because it is in accordance with the theory put forward by Gomez FC (2010: 42), William H. Mobley (2011: 159) and Veithzal Rivai (2011).

\section{Effect of Training on Job Satisfaction}

Malek, et al. (2018), found a significant and positive effect of the independent variables of the training program on the dependent variable of job satisfaction. This influence is built by the relationship between dimensions of the training program variables such as manager training, the amount of training, perceived quality of training, provided necessary information to do the job, prepared me to complete my job responsibilities with the dimensions of job satisfaction The job itself Salary / Wages, Promotion, Supervision, Colleagues. Youngsoo Choi and Duncan R.Dickson (2014), found a significant and positive effect of the program training variable on the dependent variable of job satisfaction. This influence is built by the relationship between dimensions of the training program such as the amount of training, perceived quality of training, provided information necessary to do the job with the dependent variable dimensions of job satisfaction such as the Job itself, Salary / Wages, Promotion, Supervision, Colleagues. According to Cheng.et.al (2013), training has a significant and positive effect on job satisfaction. This relationship is built by the relationship between dimensions of the independent variables of training programs such as expectations for specific skills fulfilled training, expectations for general skills training fulfilled, expectations for operational factors fulfilled, expectations for intra organizational outcomes fulfilled, expectations for interorganizational outcomes fulfilled with dimensions of the dependent variable The work itself, Salary / Wages, Promotion, Supervision, and Colleagues.

From the results of the analysis conducted by Malek, et al. (2018), Youngsoo Choi and Duncan R. Rickson (2014), Cheng.et.al. (2013), although using their respective approaches it can be concluded that there is an influence from the independent variable of training on the dependent variable is job satisfaction. Henceforth researchers will use an approach from the research results of Malek, et al. (2018), Youngsoo Choi and Duncan R.Dickson (2014), Cheng.et.al. (2013), because it is in accordance with the theory put forward by Gomez FC ( 2010: 42), William H. Mobley (2011: 159) and Mangkunegara (2011: 57). Meier (2015) found a significant and positive effect of the independent variable job satisfaction on the dependent variable of employee performance. This relationship is built by the relationship between dimensions of the independent variables of job satisfaction $(Z)$ such as the job itself, salary / wages, promotion, supervision, work colleagues with variable dimensions of employee performance such as quantity of work, quality of work, job knowledge, creativeness , cooperation, dependability, initiative, and personal qualities. 


\section{Effect of Compensation on Performance}

According to Yu-Li Tao.et.al (2015), that the significant and positive influence of the independent variable compensation on the dependent variable of employee performance is built through the relationship between dimensions of compensation variables such as direct compensation, and indirect compensation with dimensions of performance variables such as the dimensions of work quantity, work quality, work knowledge, creativity, cooperation, trustworthiness, initiative, and personal quality. (Firmandari., 2014) in one of the analyzes of his research found that the effect of compensation on performance was built by the relationship of dimension variables such as salary, benefits, bonuses from the compensation dimension to performance dimensions such as completing work on time, getting benefits according to the existing rules, work according to job description, work in accordance with standard operating procedures, meet work plans / targets set by superiors / leaders, able to complete work properly, able to work together with others (team) in carrying out work, initiative, and discipline. Jane Nelima Wekesa (2013), said that the positive and significant effect of compensation on employee performance is influenced by the dynamics of the relationship between dimensional variables such as salary, meal allowance, overtime, and loans. Compensation will affect performance because compensation is a major component to improve the performance of each employee ((Darma, 2017)

\section{Effect of Training on Performance}

According to Mangkunegara, (2015) The independent variable of Training has a positive and significant influence on the dependent variable Employee Performance through the relationship between instructor, participant, material, method and objective dimensions with Employee Performance dependent variable dimensions such as task performance, behavior, and character. (AE Rowell a, 2013). That the independent variable of the training program has a positive effect on employee performance through a direct relationship between the indicators of the Training Program Variable with the Employee Performance dependent Variable Indicator. (Gerald R Ferris, 2018) argues that the independent variable of training has a positive and significant influence on the dependent variable of employee performance through the relationship between instructor, participant, material, method and objective dimensions with the dependent variable dimensions of Employee Performance such as task performance, behavior, and nature .

From the opinions of the experts above about the effect of training on performance, it can be synthesized that there is an influence of training variables on employee performance.

\section{Effect of Satisfaction on Performance}

Rijamampianina (2015), suggests that there is a significant and positive influence of Compensation on employee performance. This relationship is built by the relationship between dimensions of the independent variables of job satisfaction such as the job itself, salary/wages, promotion, supervision, work colleagues with variable dimensions of employee performance such as quantity of work, quality of work, job knowledge, creativeness, cooperation, dependability, initiative, and personal qualities. This relationship is built by the relationship between dimensions of the independent variables of job satisfaction such as the job itself, salary / wages, promotion, supervision, work colleagues with variable dimensions of employee performance such as quantity of work, quality of work, job knowledge, creativeness, cooperation, dependability, initiative, and personal qualities. Significant and positive influence of the independent variables of job satisfaction on the dependent variable of employee performance is built by the existence of a relationship between dimensions of the independent variables of job satisfaction such as the Job itself, Salary / Wages, Promotion, Supervision, Colleagues with dimensions of performance variables such as 
quantity of work, quality of work, job Knowledge, creativeness, cooperation (Jan Wynena, 2019)

From the results of an analysis of research conducted by Rasoava Rijamampianina (2015), Meier (2015), Rajan D. (2017), Wynena.et.al (2019), and Lee (2017), although using each approach, it can be synthesized that there is an influence of the independent variable of the training program on the dependent variable of job satisfaction and the dependent variable of performance. Henceforth researchers will use an approach from the results of research Rasoava Rijamampianina. (2015), Meier (2015), Rajan D. (2017), and Lee (2017), because it is consistent with the theory put forward by Gomez FC (2010: 42) and William H. Mobley (2011: 159).

\section{Effect of Compensation on Work Performance through Job Satisfaction}

According to Yu-Li Tao.et.al (2015), that significant and positive influence of the independent variable compensation on the dependent variable of employee performance is built through employee satisfaction.

From the severe opinion of the experts above, it can be concluded that compensation affects the performance through job satisfaction.

\section{Effect of Training on Performance through Job Satisfaction The}

Purpose of the training is to improve the ability of employees to carry out their duties so that it will create effective and efficient performance therefore employees will be satisfied with their work (Ying Cheng, Franz Waldenberg, 2013). Choi and.Dickson (2014) in an analysis of their research stated that training affects employee job satisfaction. According to Kristin Malek, Shery Fried Kline, Robin DiPietro (2018) that the training variable has a direct or indirect effect on employee job satisfaction.

From the severe opinion of the experts above, it can be concluded that training influences performance through job satisfaction. Based on the explanation above about the flow of thought between research variables by referring to the results of previous research and expert opinion, it can be illustrated through the framework of the research model as follows:

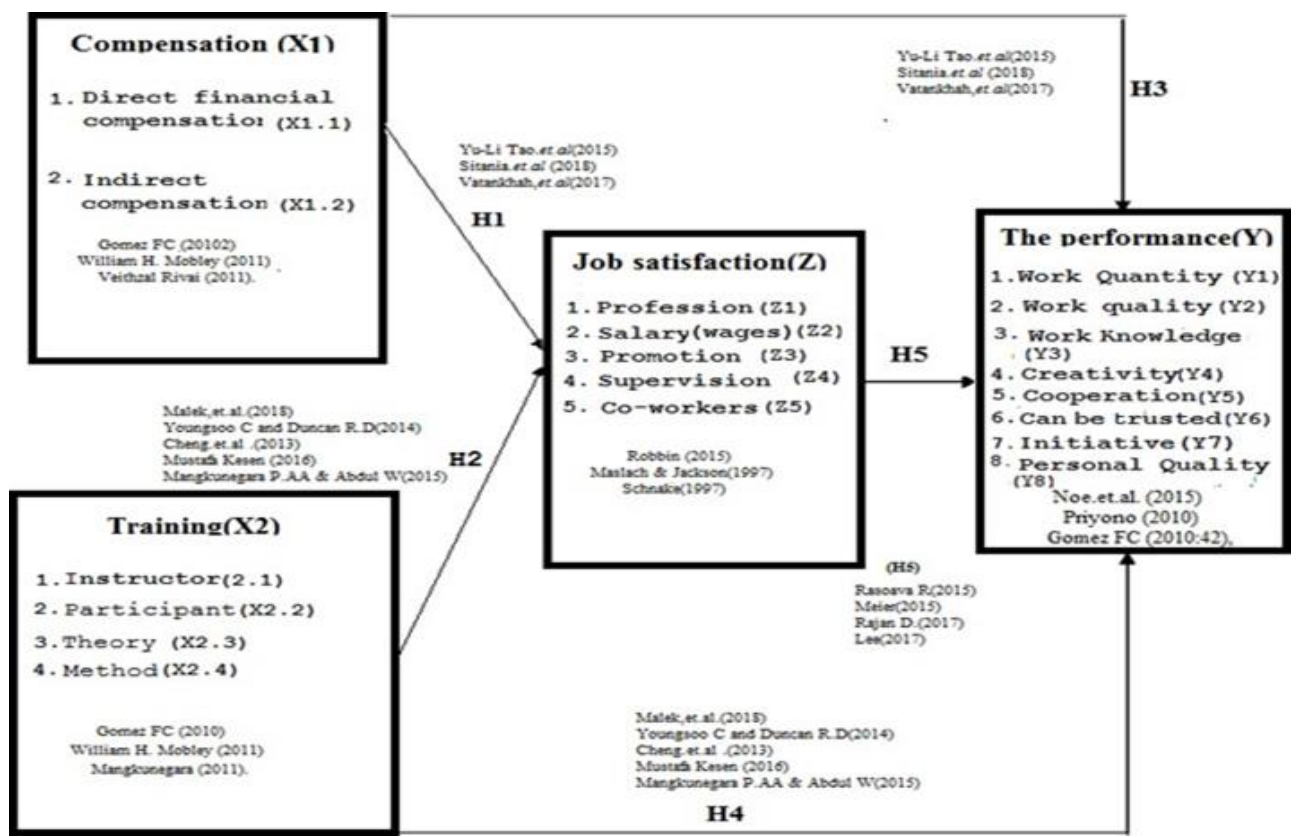

Picture 2. Concetual Framework

Source: Data processed by researchers (2019) 


\section{Research Hypothesis}

1. H1: Compensation has a positive effect on job satisfaction

2. H2: Training has a positive effect on job satisfaction

3. H3: Compensation has a positive effect on performance

4. H4: Training has a positive effect on performance

5. H5: Job satisfaction has a positive effect on performance

6. H6: Compensation has a positive effect on performance through job satisfaction

7. H7: Training has a positive effect on performance through job satisfaction

\section{RESEARCH METHODOLOGY}

This research is a quantitative study using analysis tools of the Lisrel 8.8 SEM Program. The number of respondents was 105 employees of PT. Sumber Harapan Abadi (DataPrint). The sampling technique in this study was purposive non-probability sampling using the Isaac and Michael method approach.

\section{RESULT AND DISCUSSION}

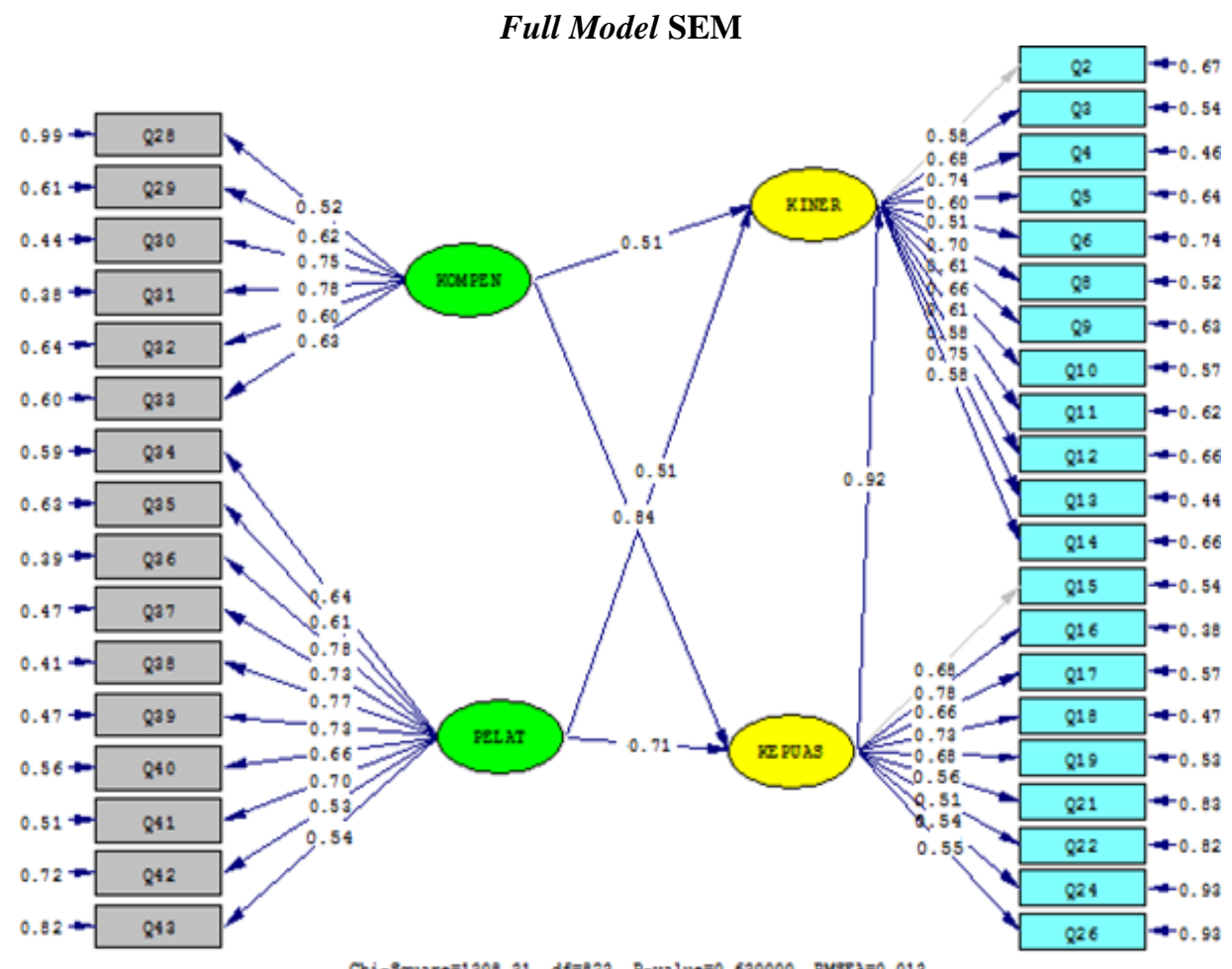

Picture 3. Full model SEM Standaridize Solution

Source: Data processed by researchers (2019)

Based on Figure 3 the number of observer variables or the number of indicator variables on the latent performance variable/KINER (Y) after experiencing a model improvement with a loading factor value is $\geq 0.5$, but for indicator variables Q1 and Q7 become lost because the loading value of these two factors does not meet the requirements $\geq$ 0.5 so that the researcher drops the model. In the latent variable satisfaction / SATISFACTION $(Z)$ the observer variable that does not meet the requirement $\geq 0.5$ is the observer variable Q20 and Q27 for that researcher drops it from the model. For observer variable in compensation latent variable/COMPENT (X1) and observer variable in training latent variable/PELAT (X2), all of them meet the loading factor requirements. 
Likewise for the requirements of a fit model after undergoing treatment in this research model has fulfilled the fit model requirements, as shown in the RMSEA value with a value of 0.013 where a fit model requires an RMSEA value close to zero. The P-Value in this study has changed and meets the requirements of 0.63 and the value of the comparison between Chi-Square and df is <2. Thus, in terms of model compatibility and factor loading value requirements, all values meet the model fit requirements and can be interpreted as model fit. The following researchers include the model fit indicator in table 1, where the model fit indicator describes the measurement process in this study further:

Table 1. Indicator Fit Model

\begin{tabular}{|c|c|c|c|}
\hline Indikator & Item & Indicator & Item \\
\hline PERFORMANCE (Y) & & SATISFACTION (Z) & \\
\hline Work Quantity (Y1) & Q2 & & Q15 \\
\hline \multirow{2}{*}{ Work quality (Y2) } & Q3 & \multirow{2}{*}{ The work itself $(\mathrm{Z} 1)$} & Q16 \\
\hline & Q4 & & Q17 \\
\hline \multirow{2}{*}{ Work knowledge (Y3) } & Q5 & & Q18 \\
\hline & Q6 & Salary / wages (Z2) & Q19 \\
\hline Creativity (Y4) & Q8 & Promotion (Z3) & Q21 \\
\hline \multirow{2}{*}{ Cooperation (Y5) } & Q9 & & Q22 \\
\hline & $\mathrm{Q} 10$ & Supervision (Z4) & Q24 \\
\hline \multirow{2}{*}{ Trustworthy (Y6) } & Q11 & \multirow{4}{*}{ Coworkers (Z5) } & \multirow{4}{*}{ Q26 } \\
\hline & Q12 & & \\
\hline \multirow{2}{*}{ Initiative (Y7) } & Q13 & & \\
\hline & Q14 & & \\
\hline \multicolumn{2}{|l|}{ COMPENSATION (X1) } & \multirow[t]{3}{*}{ TRAINING (X2) } & \\
\hline \multirow{3}{*}{ Direct compensation (X1.1) } & Q28 & & Q34 \\
\hline & Q29 & & Q35 \\
\hline & Q30 & \multirow{2}{*}{ Participants (X2.2) } & Q36 \\
\hline \multirow{7}{*}{ Indirect compensation (X1.2) } & & & Q37 \\
\hline & 031 & \multirow{3}{*}{ Material (X2.3) } & Q38 \\
\hline & & & Q39 \\
\hline & Q32 & & Q40 \\
\hline & \multirow{3}{*}{ Q33 } & \multirow{2}{*}{ Method (X2.4) } & Q41 \\
\hline & & & Q42 \\
\hline & & Destination (X2.5) & Q43 \\
\hline
\end{tabular}

Source: Data processed by researchers (2019)

\section{Comfirmatory Factor Analysys}

\section{Test Validity and Reliability of the 1st Order CFA}

The validity test of an instrument is determined by the magnitude of the path coefficient between the observation variable and its latent variable. The value of the path coefficient can be considered valid if it has a value of $\geq 0.5$ (Edi Riadi: 2018) while to test the reliability of an instrument, it can be seen from the CR and AVE. According to Hair, at.el (Hartono, 2017), the higher thevalue factor loading, the more important the role of loading is in interpreting the factor matrix. Role of thumb used for convergent validity is loading factor $>0.7$ and Average 
Variance Extracted (AVE) $>0.5$, although AVE value> 0.4 is still acceptable. Following is the table of results of the validity test of Performance variable (Y):

Table 2. Test Validity and Reliability of 1st Order CFA Performance (Y)

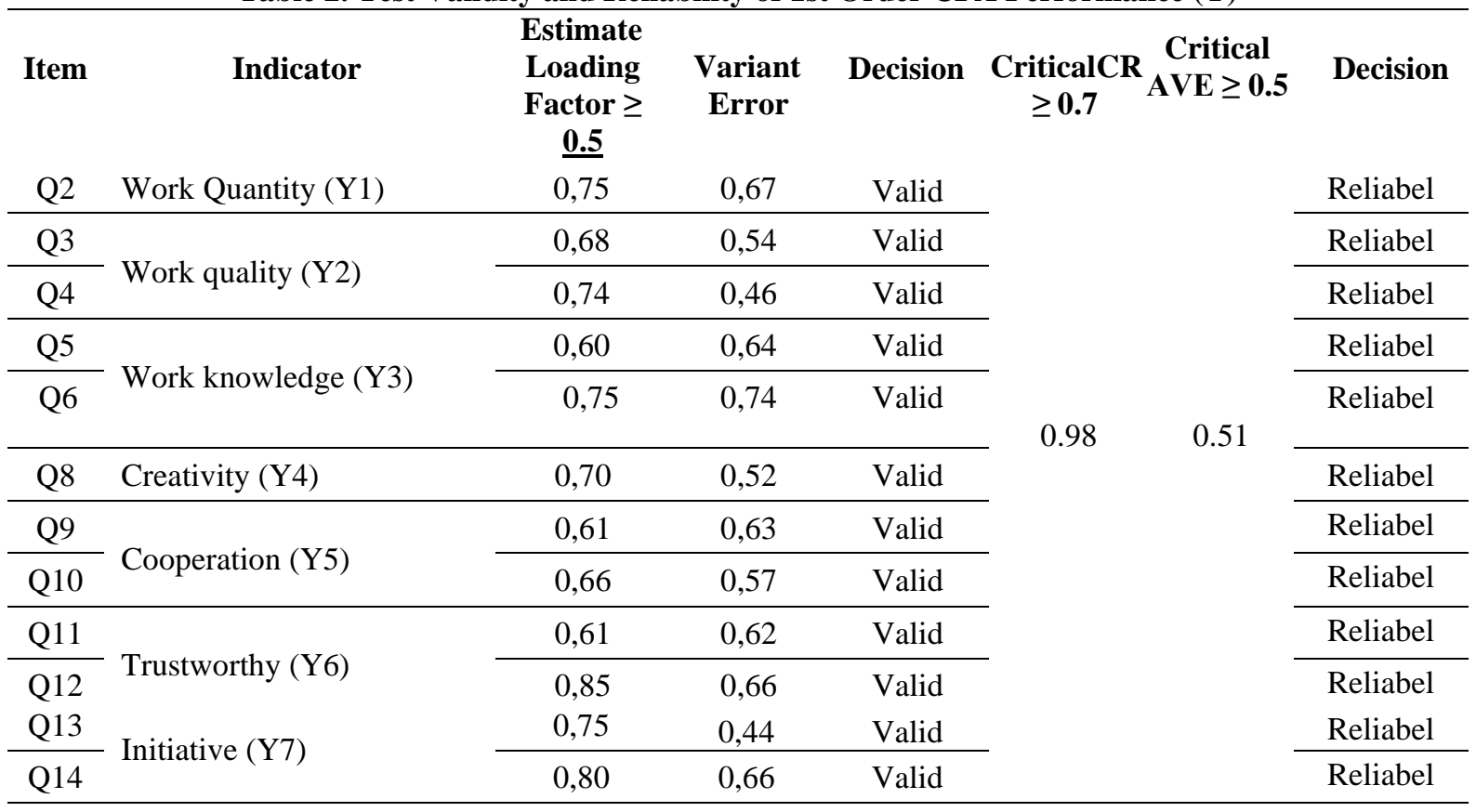

Source: Data processed by researchers (2019)

Refer to table 1 where all observer variable loading factor values that make up the latent performance / KINER variable (Y) are greater or equal to the loaded factor loading value of 0.5 . Thus it can be stated that the observer variable that forms the latent variable performance / KINER (Y) is valid. While the value of Construct Reliability (CR) and Average Variance Extracted (AVE) observer variables that form performance / KINER (Y) $\geq$ 0.7 and $\geq 0.5$, it can be stated that the latent variable performance / KINER(Y) formed by 12 observer variables is reliable.

Table 3. Test Results of Validity \& Reliability of Latent Satisfaction Variables (Z)

\begin{tabular}{|c|c|c|c|c|c|c|c|}
\hline Item & Indicator & $\begin{array}{c}\text { Estimate } \\
\text { Loading Factor } \\
0.5 \geq 0.5\end{array}$ & $\begin{array}{c}\text { Variant } \\
\text { Error }\end{array}$ & Decision & $\begin{array}{c}\text { Critical } \\
C R \geq 0.7\end{array}$ & $\begin{array}{c}\text { Critical } \\
\mathrm{AVE} \geq 0.5\end{array}$ & Decision \\
\hline Q15 & \multirow{4}{*}{ The work itself $(\mathrm{Z} 1)$} & 0,68 & 0,54 & Valid & \multirow{9}{*}{0.87} & \multirow{9}{*}{0.5} & Reliabel \\
\hline Q16 & & 0,78 & 0,38 & Valid & & & Reliabel \\
\hline Q17 & & 0,66 & 0,57 & Valid & & & Reliabel \\
\hline Q18 & & 0,73 & 0,47 & Valid & & & Reliabel \\
\hline Q19 & Salary / wages (Z2) & 0,68 & 0,53 & Valid & & & Reliabel \\
\hline Q21 & \multirow{2}{*}{ Promotion (Z3) } & 0,56 & 0,83 & Valid & & & Reliabel \\
\hline Q22 & & 0,75 & 0,82 & Valid & & & Reliabel \\
\hline Q24 & Supervision (Z4) & 0,80 & 0,93 & Valid & & & Reliabel \\
\hline Q26 & Coworkers (Z5) & 0,75 & 0,93 & Valid & & & Reliabel \\
\hline
\end{tabular}

Source: Data processed by researchers (2019)

Based on table 3 above all the loading factor values that make up the satisfaction / CUSTOMER latent variable $(Z)$ have a loading factor value $\geq 0.5$. Therefore the observer variable that forms the latent variable satisfaction /KAPUAS(Z) can be declared valid. 
Whereas the magnitude of the value of Construct Reliability (CR) and Average Variance Extracted $(A V E) \geq 0.70$ and $\geq 0.5$. Thus the satisfaction $/ \operatorname{KEPUAS}(Z)$ variable formed by observer variables such as Q15, Q16, Q17, Q18, Q19, Q21, Q22, Q24, and Q26 can be declared reliable.

Table 4. Test Results of Validity and Reliability of Latent Variable Compensation (X1)

\begin{tabular}{|c|c|c|c|c|c|c|c|}
\hline Item & Indicator & $\begin{array}{c}\text { Estimate } \\
\text { Loading Factor } \\
0.5 \geq 0.5\end{array}$ & $\begin{array}{l}\text { Variant } \\
\text { Error }\end{array}$ & Decision & $\begin{array}{c}\text { Critical } \\
\text { CR } \geq 0.7\end{array}$ & $\begin{array}{c}\text { Critical } \\
\text { AVE } \geq 0.5\end{array}$ & Decision \\
\hline Q28 & \multirow{3}{*}{$\begin{array}{l}\text { Direct compensation } \\
\text { (X1.1) }\end{array}$} & 0,85 & 0,85 & Valid & \multirow{6}{*}{0.84} & \multirow{6}{*}{0.54} & Reliabel \\
\hline Q29 & & 0,62 & 0,62 & Valid & & & Reliabel \\
\hline Q30 & & 0,75 & 0,75 & Valid & & & Reliabel \\
\hline Q31 & \multirow{3}{*}{$\begin{array}{l}\text { Indirect compensation } \\
(\mathrm{X} 1.2)\end{array}$} & 0,78 & 0,78 & Valid & & & Reliabel \\
\hline Q32 & & 0,75 & 0,75 & Valid & & & Reliabel \\
\hline Q33 & & 0,63 & 0,63 & Valid & & & Reliabel \\
\hline
\end{tabular}

Judging from the results of the validity test in table 4.17 above, the researcher can state that the observer variable or variable indicator that forms the compensation / COMPENT latent variable $(\mathrm{X} 1)$ is valid because each observer variable has a loading factor value $\geq 0.5$. Likewise, if we look at the value of Construction Reliability (CR) and Avrage Variance Extrated $(\mathrm{AVE}) \geq 0.70$ and $\geq 0.5$. Therefore the compensation variable (KOMPEN (X1) formed by 6 observer variables can be declared reliable.

In table 4 the results of the validity and reliability of the training variable (X2) then the researcher can state that the variable observer or variable indicator that forms the training variable (X2) is valid because each observer variable has a loading factor value $\geq 0.5$. Likewise, the magnitude of the value of the Construction Reliability (CR) and Avrage Variance Extrated (AVE) $\geq 0.70$ and $\geq 0.5$. Because the value of the Construction Reliability (CR) and Avrage Variance Extrated (AVE) $\geq$ Critical Value, the training variable / PLATE (X2) can be declared reliable. The following is table 5 of the results of the validity and reliability test of the training instrument:

Table 5. Results of Latent Reliability Tests for Training Variables (X2)

\begin{tabular}{|c|c|c|c|c|c|c|c|}
\hline Item & Indikator & $\begin{array}{c}\text { Estimate } \\
\text { Loading } \\
\text { Factor } \\
\mathbf{0 . 5} \geq \mathbf{0 . 5}\end{array}$ & $\begin{array}{c}\text { Variant } \\
\text { Error }\end{array}$ & Decision & $\begin{array}{c}\text { Critical } \\
\mathrm{CR} \geq 0.7\end{array}$ & $\begin{array}{c}\text { Critical } \\
\text { AVE } \geq 0.5\end{array}$ & Decision \\
\hline Q34 & \multirow{2}{*}{ Instructor X2.1) } & 0,64 & 0,59 & Valid & \multirow{10}{*}{0,91} & \multirow{10}{*}{0,55} & Reliabel \\
\hline Q35 & & 0,61 & 0,63 & Valid & & & Reliabel \\
\hline Q36 & \multirow{2}{*}{ Participants (X2.2) } & 0,78 & 0,39 & Valid & & & Reliabel \\
\hline Q37 & & 0,73 & 0,47 & Valid & & & Reliabel \\
\hline Q38 & \multirow{3}{*}{ Material (X2.3) } & 0,77 & 0,41 & Valid & & & Reliabel \\
\hline Q39 & & 0,73 & 0,47 & Valid & & & Reliabel \\
\hline Q40 & & 0,66 & 0,56 & Valid & & & Reliabel \\
\hline Q41 & \multirow{2}{*}{ Method (X2.4) } & 0,70 & 0,51 & Valid & & & Reliabel \\
\hline Q42 & & 0,85 & 0,72 & Valid & & & Reliabel \\
\hline Q43 & Destination (X2.5) & 0,87 & 0,82 & Valid & & & Reliabel \\
\hline
\end{tabular}

Source: Data processed by researchers (2019) 
From a series of validity and reliability test results as described above, all observed variables and latent variables have been declared valid and reliable, so that further analysis can be done. Testing in the next stage is to analyze the suitability of the model as a whole or the Goodness of Fit (GOF) test. This test evaluates the overall model whether the resulting model is a fit model or not.

\section{Second Order CFA (2ndCFA) Model Fit Test}

This test will evaluate whether the overall model produced is a fit model or not, meaning that if the overall model after the GOF test produces a fit model, it means that the sample covariance matrix is not much different from the estimated covariance matrix so that the model can be expressed in terms of model compatibility already fit or Goodness of fit. Based on the results of the SEM print-out that the research model can be seen in this study is a good model.

The series of goodness of fit tests that will be conducted by researchers such as ChiSquare and P-Value tests, Non Centrality Parameters (NCP), Root Mean Square Error of Approxation (RMSEA), Expected Cross Validation Index (ECVI), Akaike Information Criterion or commonly called the AIC model, Consistent Information Criterion (CAIC), Normed Fit Index (NFI), Tucker Lewis Index or NNFI, Parsimonious Normed Fit Index (PNFI), Comparative Fit Index (CFI), Incremental Fit Index (IFI), Standardized Root Mean Square Residual (SRMR), Goodness of Fit Index (GFI), Adjusted Goodness of Fit Index (AGFI), and Parsimonious Goodness of Fit (PGFI). The following researchers include the results of the overall model fit test or goodness of fit in the table:

Table 6. Model Suitability Test (Goodness of Fit)

\begin{tabular}{|c|c|c|c|}
\hline GOF SIZE & $\begin{array}{c}\text { ESTIMATION } \\
\text { RESULTS } \\
\end{array}$ & CRITERIA & Decision \\
\hline \multirow{2}{*}{ Statistcs $\lambda^{2}$} & $\mathrm{df}=823$ & $0 \leq \lambda^{2} \leq 2 \mathrm{df}$ & \multirow{2}{*}{ Fit } \\
\hline & $\lambda^{2}=1308.31$ & $2 \mathrm{df}<\lambda^{2} \leq 3 \mathrm{df}$ & \\
\hline P-Value & 0.63 & $0.05 \leq \mathrm{p} \leq 1.00$ & Fit \\
\hline $\mathrm{NCP}$ & 103.25 & $<\lambda^{2}$ & Fit \\
\hline RMSEA & 0.013 & RMSEA $\leq 0.08$ & Fit \\
\hline ECVI & 7.89 & $<$ Saturated ECVI(8.14) & Fit \\
\hline Model AIC & 655.47 & $<$ Saturated AIC(724) & Fit \\
\hline Model CAIC & 1879.20 & < Saturated CAIC(1230.67) & Fit \\
\hline NFI & 0.95 & NFI $>0.90$ & Fit \\
\hline NNFI/TLI & 0.91 & NFI $>0.90$ & Fit \\
\hline PNFI & 0.25 & PNFI $<0.5$ & Fit \\
\hline CFI & 0.99 & $\mathrm{CFI}>0.97$ & Fit \\
\hline IFI & 0.97 & IFI $>0.90$ & Fit \\
\hline RFI & 0.92 & RFI $>0.90$ & Fit \\
\hline $\mathrm{CN}$ & 223 & $\mathrm{CN}>200$ & Fit \\
\hline SRMR & 0.03 & $\mathrm{SRMR} \leq 0.05$ & Fit \\
\hline GFI & 0.95 & GFI > 0.90 & Fit \\
\hline AGFI & 0.93 & AGFI > 0.89 & Fit \\
\hline PGFI & 0.55 & PGFI $>0.5$ & Fit \\
\hline
\end{tabular}

Source: Data processed by researchers (2019) 
Referring to table 6 of the model fit test results above, it can be seen that the entire Goodness of fit test results are values that meet the requirements to state that this research model as a whole is a fit or goodness of fit model. This means that all the sample covariance metrics in this model are not much different from the estimated covariance matrices.

\section{Hypothesis Testing}

To test the hypothesis it is necessary to look at the structural equation of the SEM model of the study found in figures 3 and 4 and table 7 below. Table 7 illustrates the results of the equation test with direct and indirect effects. Direct effects such as the relationship between compensation and satisfaction variables, training variables with satisfaction, satisfaction with performance. While the indirect effect is the relationship between variables such as compensation with performance with job satisfaction mediator variables and training variables with performance with job satisfaction mediator variables. Following this the researchers included Figure 4 and Table 7:

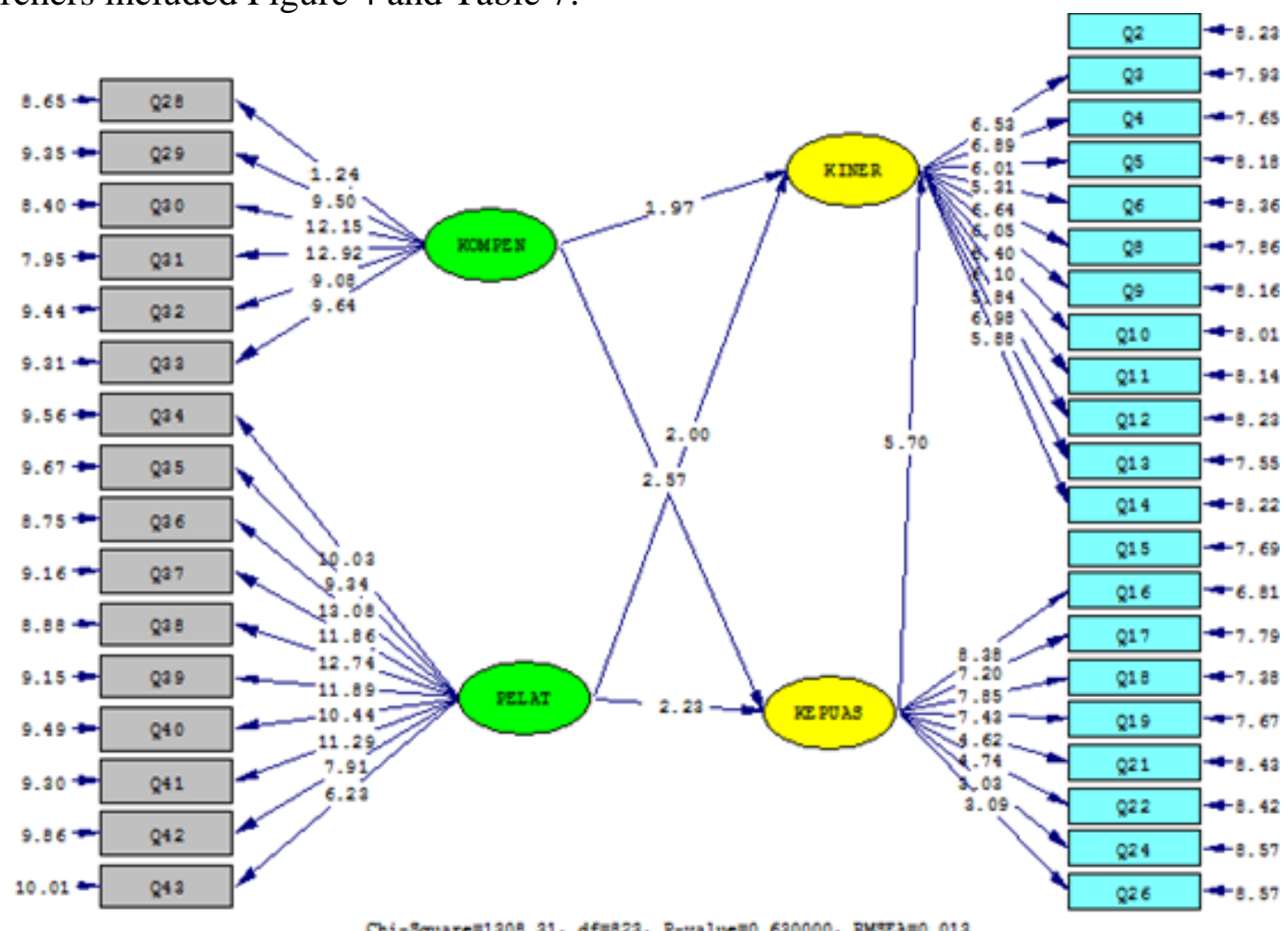

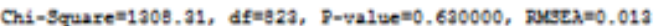

Picture 4 T-Vaalue Model 1st

Source: SEM Lisrel Output Results (2019)

To find out an effect of a significant variable or not, we can consult it with the $Z$ value of the two tailed test table at $a=0.05$, then the probability value is obtained $Z-1-(a / 2)=1-$ $(0.05 / 2)=0.975$. From the $\mathrm{Z}$ table, the value 0.975 is obtained by a $\mathrm{Z}$ score of 1.96 . A $\mathrm{Z}$ score of 1.96 is set as a critical value for significant testing (Edi Riadi, 452: 2018).

Table 7. Test Results of Direct Causal Effect (ICE) and Indirect Causal Effect (ICE)

\begin{tabular}{llcccc}
\hline \multicolumn{1}{c}{ ROUTES } & DCE & $\begin{array}{c}\text { ICE Job } \\
\text { satisfaction }\end{array}$ & t-count & t-critical & CONCLUSION \\
\hline KOMPEN $\rightarrow$ KAPUAS & 0.82 & 2.17 & 1.96 & Sigifikan \\
\hline PELAT $\rightarrow$ KAPUAS & 0.84 & 2.23 & 1.96 & Sigifikan \\
\hline KAPUAS $\rightarrow$ KINER & 0.89 & 5.70 & 1.96 & Sigifikan \\
\hline KOMPEN $\rightarrow$ KINER & 0.52 & 1.97 & 1.96 & Sigifikan \\
\hline
\end{tabular}




\begin{tabular}{llllll}
\hline PELAT $\rightarrow$ KINER & 0.51 & & 2.01 & 1.96 & Sigifikan \\
\hline KOMPEN $\rightarrow$ KINER & 0,73 & 0,73 & 2.29 & 1.96 & Sigifikan \\
\hline PELAT $\rightarrow$ KINER & 0.62 & 0.62 & 2.02 & 1.96 & Sigifikan \\
\hline
\end{tabular}

Source: Data processed by researchers (2019)

\section{Testing the First Hypothesis}

H1: Compensation has a positive and significant effect on job satisfaction

Based on the analysis results of Figure 3 Full Path Diagram Basic Standardize Solution CFA2, and Figure 4 Full Path Diagram Basic Model T-Value CFA 2, and table 7 Results of Direct Causal Effect Tests (ICEe) and Indirect Causal Effect (ICE), it can be stated that there is a very strong and significant influence of the compensation / COMPENT variable (X1) on the latent variable of job satisfaction /KEPUAS(Z). Therefore the hypothesis which states "Compensation has a positive and significant effect on job satisfaction", can be accepted.

\section{Testing the Second Hypothesis}

$\mathrm{H} 2$ : The training program has a positive and significant effect on job satisfaction.

Referring to the analysis results of Figure 4 Full Path Diagram Basic Standardize Solution CFA2, and Figure 4 Full Path Diagram Basic Model T-Value CFA 2, and table 7 Direct Test Results Causal Effect (ICEe) and Indirect Causal Effect (ICE), it can be stated that there is a strong and significant influence of the training variable / PELAT (X2) on the latent variable of job satisfaction /KEPUAS(Z). Therefore the hypothesis which states "The training program has a positive and significant effect on job satisfaction" can be accepted.

\section{Third Hypothesis Testing}

H3: Compensation has a positive and significant effect on employee performance

Referring to the analysis results of Figure 3 Full Path Basic Standardize Solution CFA2 diagram, and Figure 4 Full Path Diagram Basic Model T-Value CFA 2, and table 7 Direct Causal Test Results Effect (ICEe) and Indirect Causal Effect (ICE),, it can be stated that there is a strong and significant influence of compensation latent variable / COMPENT (X1) on performance latent variable / KINER (Y).Therefore the hypothesis stating "Compensation positive and significant effect on employee performance " can be accepted.

4. Testing the fourth hypothesis

H4: Training has a positive and significant effect on employee performance

Based on the analysis results of Figure 3 Full Path Basic Standardize Solution CFA2 diagram, and Figure 4 Full Path Diagram Basic Model T-Value CFA 2, and table 7 Direct Test Results Causal Effect (ICEe) and Indirect Causal Effect (ICE), it can be stated that there is a fairly strong and significant influence of the training latent variable / PELAT (X2) on the performance latent variable / KINER (Y). Therefore the hypothesis which states "Training has a positive and significant effect on employee performance" can be accepted.

\section{Testing the Fifth Hypothesis}

H5: Job satisfaction has a positive and significant effect on employee performance

Based on the results of the image analysis of Figure 3 Full Path Diagram Basic Standardize Solution CFA2, and Figure 4 Full Path Diagram Basic Model T-Value CFA 2, and table 7 Test Results Direct Causal Effect (ICEe) and Indirect Causal Effect (ICE), it can be stated that there is a very strong and significant influence of the latent variable of job satisfaction /KEPUAS(Z) on the latent variable of performance / KINER (Y). Therefore the hypothesis is states "Job satisfaction has a positive and significant effect on employee performance" acceptable. 


\section{Testing Sixth Hypothesis}

H6: Compensation has a positive effect on performance through job satisfaction.

Based on the results of image analysis, Figure 3 Full Path Basic Standardize Solution CFA2 diagram, and Figure 4 Full Path Diagram Basic Model T-Value CFA 2, and table 7 Direct Test Results Causal Effect (ICEe) and Indirect Causal Effect (ICE), it can be stated that there is a very strong and significant influence of the Compensation latent variable (X1) on the performance latent variable / KINER (Y) through job satisfaction. Therefore the hypothesis which states "Compensation has a positive and significant effect on employee performance through Job Satisfaction" can be accepted.

\section{Seventh Hypothesis Testing}

H7: Training has a positive effect on performance through job satisfaction.

Based on the results of image analysis, Figure 3 Full Path Basic Standardize Solution CFA2 diagram, and Figure 4 Full Path Diagram Basic Model T-Value CFA 2, and table 7 Results of Direct Causal Effect Test (ICEe) and Indirect Causal Effect (ICE), it can be stated that there is a very strong and significant influence of the training latent variable (X2) on the performance latent variable / KINER (Y) through job satisfaction. Therefore the hypothesis which states "Training has a positive and significant effect on employee performance Job Satisfaction" can be accepted.

From the results of the hypothesis test analysis, it states that all exogenous variables affect endogenous variables. In empirical fact the results of the analysis of this hypothesis prove the influence of these five latent variable relationships. This informs the results of research conducted by Yu-Li Tao.et.al (2015), itania.et.al (2018), Vatankhah, et.al (2017), Bryant, et.al (2013), Rubel.et .al, (2015), Veithzal Rivai (2011: 357). Malek, et.al. (2018), Youngsoo Choi and Duncan R.Dickson (2014), Cheng.et.al. (2013), Mustafa Kesen (2016), Anwar Prabu Mangkunegara and Abdul Waris (2015) and Idrees.et .al (2015) because it is in accordance with the theory put forward by Gomez FC (2010: 42), William H. Mobley (2011: 159) and Mangkunegara (2011: 57), Rasoava Rijamampianina (2015), Meier (2015), Rajan D. (2017), Lee (2017), Gomez FC (2010: 42) and William H. Mobley (2011: 159).

\section{Discussing}

1) Compensation has positive and significant effect on job satisfaction

Compensation is built by six observer variables and two dimensional variables. Observer variables will measure the construct of two dimensions of compensation variables, namely the variable direct financial compensation and indirect compensation. From the results of the analysis in figures 4.4 and 4.5 inform that the influence of the six observer variables on the variable of direct compensation and indirect compensation is very large and significant. This implies that employee perceptions of compensation received both physically in the form of salaries, bonuses, incentives and work facilities such as social protection and health insurance as well as non-physical means that a company's recognition or appreciation of employees will have an impact on employee performance and each employee will motivated by work achievement.

Other effects with the existence of a good compensation program from the company for employees, the level of employee satisfaction with the company will be higher, this has been proven in the results of this study that compensation is very strong influence on employee satisfaction. When employees are satisfied with the compensation provided by the company, the company will get positive things from the implementation of this compensation, one of which is the company will easily retain employees who excel to continue working at the company. 
So this result can be stated that to increase employee job satisfaction with the company one of the ways that the company can do is to provide compensation programs that are felt to be fair by employees such as giving salaries, bonuses, incentives, benefits, social programs, health insurance, and guarantees retirement and adequate pension programs. In addition to the financial compensation program, the company can also develop a non-financial compensation program, namely the existence of an award or recognition of work performance and the presence of employees in the company. This program can be developed as a training provider to increase employee knowledge to support their work, create a safe and comfortable work environment, have professional and competent supervision, build a solid and supportive work team, have career path certainty, have employee leave, have work hours that is flexible and always values every employee's achievement by developing a professional and honest reward and punishment program.

These findings confirm the results of research conducted by Yu-Li Tao.et.al (2015), Sitania.et.al (2018), Vatankhah, et.al (2017) because they are in accordance with the theory put forward by Gomez FC (2010 : 42), William H. Mobley (2011: 159) and Veithzal Rivai (2011: 357).

\section{2) The training program has a positive and significant effect on job satisfaction.}

Latent training variables are measured by 5 dimensional variables such as instructors, participants, materials, methods, and training objectives, and the five dimensional variables aremeasured re-by 10 observer variables. From the analysis results in figures 3 and 4 and in table 7 inform us that the influence of the five dimensional variables that make up the training variable has a very strong and very significant effect. The magnitude of the effect of training and the significance of training on employee job satisfaction because employees have interpretations of the training itself. With a training program in the company, employees will understand and take responsibility for the work that the company is responsible for themselves. In addition to understanding the job responsibilities with training, it will minimize mistakes that can cause harm to himself or the company. Employees will be proud because taking part in a training program will improve their skills and change their attitude. Also according to the employee's interpretation that training will increase productivity which has an effect on progress for the employee itself so that he will upgrade the income he gets.

The results of the analysis on the significance of the indirect effect coefficient test show us that the effect of training latent variables on satisfaction observer variables has a small and significant effect. Which means that any changes that occur in the training latent variable will affect the observer variable forming the latent variable satisfaction. Changes to the latent variable of training have sensitivity to changes in the observer variable satisfaction so that whatever the results of the training will raise the level of employee satisfaction in working for the company.

The results of this study are consistent with the results of research conducted by Malek, et al. (2018), Youngsoo Choi and Duncan R.Dickson (2014), Cheng.et.al. (2013), Mustafa Kesen (2016), Anwar Prabu Mangkunegara and Abdul Waris (2015) and Idrees.et.al (2015) because it is in accordance with the theory put forward by Gomez FC (2010: 42), William H. Mobley (2011: 159) and Mangkunegara (2011: 57).

\section{3) Compensation has a positive and significant effect on employee performance}

As mentioned earlier that compensation will affect company performance. Compensation can trigger changes in behavior and attitudes in employees the better. When compensation is interpreted by employees which is proper and fair, employees will feel 
treated fairly by the company. This will trigger a good relationship between the company and employees.

Providing compensation by the company such as providing salaries, bonuses, incentives, etc., if it is felt appropriate and fair by employees, it will trigger an increase in the performance of every employee in the company. Another impact of giving fair and equitable compensation will trigger company employees to excel and work very hard. The output from giving compensation to employees, the quantity of work, quality of work, work knowledge of employees will increase because employees feel that what they have done now gets satisfying reciprocity. In addition to the three variables above, the output from the compensation giving rise to creativity, cooperation, trustworthiness and initiative from employees will be even higher.

The results of this study confirm the results of research conducted by Rasoava Rijamampianina research (2015), Meier (2015), Rajan D. (2017), and Lee (2017), because they are in accordance with the theory put forward by Gomez FC (2010: 42) and William H. Mobley (2011: 159).

\section{4) Training has a positive and significant effect on employee performance}

Referring to the results of the analysis of Figure 3 Full Path Diagram Basic Standardize Solution CFA2, and Figure 4 Full Path Diagram Basic Model T-Value CFA 2, as well as table 7 test the significance of the direct effect coefficient test, inform us that the training latent variable is strong enough to have a significant effect on the performance latent variable. HR training at a company is very closely related to employee performance at the company. The training program is seen as one of the factors that can improve employee performance and increase employee confidence. The training program has an impact on improving the ability and skills of employees in completing the work assigned to them.

These findings confirm the results of research conducted by Yu-Li Tao.et.al (2015), Sitania.et.al (2018), Vatankhah, et.al (2017) because they are in accordance with the theory put forward by Gomez FC (2010 : 42), William H. Mobley (2011: 159) and Veithzal Rivai (2011: 357).

\section{5) Job satisfaction has a positive and significant effect on employee performance.}

Judging from the results of the hypothesis analysis, SEM printout results contained in Figure 3: Full Path Diagram Basic Standardize Solution CFA2, and Figure 4: Full Path Diagram Basic Model T-Value CFA 2, and tables. 7 test the significance of the direct effect coefficient informs us that employee satisfaction is very influential on employee performance. There are five variables that can encourage employees to be satisfied with the company. First, employees will feel satisfied if they feel they are compatible with the work assigned to them. The second variable is salary or wages where the employee will feel satisfaction in working if the salary or wage is felt to be reasonable and fair and in accordance with the demands of the job. The third variable is employee satisfaction will arise if they feel valued and cared for by the company because of the promotion to a higher level. The fourth variable is the employee will feel fast if the supervision of a credible and trustworthy company and the fifth variable is the environment or work colleagues where the environmental influence on employee satisfaction is significant. A safe, comfortable environment and always supporting employees in work causes employees to enjoy carrying out their duties. The five variables according to the results of the analysis are very influential and significant to the creation of employee job satisfaction. 
The results of the study prove that the effect of satisfaction on performance is very strong and significant, which means that improvements such as salary, employee conditions, environmental conditions, credible promotions and supervision will affect the quantity of work performance of employees, the quality of work of employees, increase employee work knowledge, increase cooperation between employees and the emergence of initiatives in employees in doing better jobs. This can be seen from the results of the analysis on the coefficient of influence between job satisfaction variables with all observer variables that form performance variables. In the analysis of the influence contained in table 4.28 it can be seen that the effect of satisfaction variables on the performance observer variable is quite strong and significant.

Therefore it can be interpreted that any changes to employee satisfaction will have an impact on employee performance. The results of this study are consistent with the results of research conducted by Malek, et al. (2018), Youngsoo Choi and Duncan R.Dickson (2014), Cheng.et.al. (2013), Mustafa Kesen (2016), Anwar Prabu Mangkunegara and Abdul Waris (2015) and Idrees.et.al (2015) because it is in accordance with the theory put forward by Gomez FC (2010: 42), William H. Mobley (2011: 159) and Mangkunegara (2011: 57).

\section{6) Compensation has a positive and significant effect on employee performance through} Job Satisfaction

Referring to Hypothesis analysis results, results printout SEMcontained in Figure 3 Full Path Diagram Basic Standardize Solution CFA2, and Figure 4 Full Path Diagram Basic Model T-Value CFA 2, as well as table 7 significance coefficient influence test, we can see that in addition to the direct influence of Compensation on employee Performance there is also an indirect effect where Compensation will affect employee performance after first encouraging the motivation of each individual employee to work better. the indirect effect of compensation on performance through the satisfaction variable has a high path coefficient. This value can be interpreted that the effect of compensation on performance variables after going through the mediator variable satisfaction has a strong and significant influence. Likewise, the effect of training variables on performance variables after going through satisfaction mediation variables has a strong and significant influence. While the indirect effect of compensation latent variables on observer variables that make up the performance variable even though it has a significant T- Value but the path coefficient value is low, it can be stated that the compensation effect on the observer variables that make up the performance variable is low but significant which means that every change occur in the compensation variable will have an impact on the observer variable that forms the performance variable.

The results of this study are new discoveries in this study because previous researchers such as those conducted by Yu-Li Tao.et.al (2015), Sitania.et.al (2018), Vatankhah, et.al (2017), Rasova Rijamampianina (2015), Meier (2015), Rajan D. (2017), and Lee (2017) only partially analyzed the effect of Compensation on employee satisfaction and the effect of Compensation on employee performance.

\section{7) Training has a positive and significant effect on employee performance through Job Satisfaction}

Based on the results of the hypothesis analysis, SEM printout results contained in Figure 3 Full Path CFA2 Basic Standardize Solution Diagram, and Figure 4 Full Path Diagram Basic Model T-Value CFA 2, and Table 7 test the significance of the coefficient of influence in addition to the direct effect of training on Performance and Satisfaction, there are also indirect effects of training on employee performance after employee job 
satisfaction. although the training of observer variables forming the performance variable has a low influence but its influence is significant. This implies that the slightest change in employee perceptions of training will affect employee satisfaction and will also affect employee performance. The magnitude of the effect of the satisfaction variable on the observer variables forming the performance variable in general has a low influence but this effect is very significant.

The results of this study are a novelty discovery in this study because the previous researchers as conducted by Malek, et.al. (2018), Youngsoo Choi and Duncan R.Dickson (2014), Cheng.et.al. (2013), Mustafa Kesen (2016), Anwar Prabu Mangkunegara and Abdul Waris (2015) and Idrees.et .al (2015), Yu-Li Tao.et.al (2015), Sitania.et.al (2018), Vatankhah, et.al (2017). Only partially analyze the effect of training on employee performance and the effect of training on employee performance.

\section{CONSLUSSION AND SUGESTION \\ Conslussion}

The results of this study reinforce the theory that:

1. There is a positive and significant effect of Compensation on Job satisfaction where these results are confirmed with the theory and results of previous studies.

2. There is a positive and significant effect of training on job satisfaction where these results are confirmed by theory and the results of previous studies.

3. There is a positive and significant effect of compensation on employee performance where these results are confirmed by the theory and results of previous studies.

4. There is a positive and significant effect of job training on employee performance where these results are confirmed by the theory and results of previous studies.

5. There is a positive and significant effect of job satisfaction on service performance where these results are confirmed by theory and the results of previous studies.

6. There is a positive and significant effect of Compensation on employee performance through job satisfaction where these results are confirmed by theory and previous research results.

7. There is a positive and significant effect of work training on employee performance through Job Satisfaction where these results are confirmed with theory and research results previous

\section{Suggestion}

1. To get more comprehensive results in analyzing the influence between variables in this study and to strengthen the theory, it is necessary to conduct a study or review using different research objects or in the same industry with different locations.

2. It is expected that for further analysis of the relationship of influence between variables in this study it is advisable to use a larger and more extensive number of samples, as well as adding references and more recent research reviews so that research results are accurate.

\section{REFERENCES}

A.E. Rowell a, M. B. (2013). Influence of food safety training on grocery store employees' performance of food handling practices see front matter $2013 \mathrm{Ltd}$. All rights reserved. http:/. Elsevier, 0306-9192. doi: http://dx.doi.org/10.1016/j.foodpol.2013.05.00

Adigun A. O.(Ph.D), O. I. (2017). INFLUENCE OF JOB SATISFACTION ON EMPLOYEES' PERFORMANCE IN MTN NIGERIA. ". Global Journal of Human Resource Management, 5, No.5, June, 54-60,. Diambil kembali dari (www.eajournals.org)

Alamdar Hussain Khan, Muhammad Musarrat Nawaz, Muhammad Aleem and Wasim Hamed. (2011). Impact of job satisfaction on employee performance: An empirical 
study of autonomous Medical Institutions of Pakistan. ”. African Journal of Business Management, 6 (7), 2697-2705. doi:DOI: 10.5897/AJBM11.2222

Anwar Prabu Mangkunegara, A. W. (2015). Effect of Training Competence and Discipline on Employee Performance in Company (Case Study in PT. Ansuransi Bangun Askrida). Journal Global Confereence on Business and Social Science, 1240-1251. Diambil kembali dari http://ac.els-cdn.com/S1877042815055056/1-s2.0S1877042815055056main.pdf?tid $=05276814-5898-11 \mathrm{e} 7-$ 97f400000aacb360\&acdnat $=1498279740 \_95$ da7adee72c0cfca42c97e860e40ed7 As'ad, M. (2010). Psikologi Industri. Edisi Kesebelas. Yogyakarta:: Liberty.

Bangun, W. ( 2012). Manajemen Sumber Daya Manusia. Jakarta: Erlangga. Bangun, W. ( 2012. ). Manajemen Sumber Daya Manusia. Jakarta: : Erlangga.

Bryant. Phil C, D. G. (2013). Compensation, Benefits and EmployeeTurnover: HR Strategies for RetainingTop Talent".Compensation \& Benefits Review45(3) . SAGE PublicationsReprints and permissions: sagepub.com/journalsPermissions.navD, 171175.

Darma, P. S. ( 2017). The Effect Of Compensation On Satisfaction And Employee Performance. Management and Economics Journal, 1 (1): 69-78.

Dessler, G. ( 2011). Manajemen sumber daya manusia. Jakarta: Penerbit Indeks.

Dlamini, C. M. (2018). Impact of Compensation and Benefits on Job Satisfaction. Research Journal of Business Management. doi:DOI: 10.3923/rjbm.2017.80.90

Dlamini., C. M. (2018). Impact of Compensation and Benefits on Job Satisfaction. Research Journ. Diambil kembali dari https://www.researchgate.net/publication/325959515

Firmandari., N. (2014). Pengaruh Kompensasi Terhadap Kinerja Karyawan Dengan Motivasi Kerja Sebagai Variabel Moderasi (Studi Pada Bank Syariah Mandiri Kantor Cabang Yogyakarta). Jurnal Ekonomi dan Bisnis Islam, IX(1), 25 - 34.

Gomes, F. (2010). Manajemen Sumber Daya Manusaia. Rajawali Pers.

Handoko, T. H. ( 2014). Manajemen Personalia dan Sumber Daya Manusia. Yogyakarta: BPFE.

Jane Nelima Wekesa, S. N. ( 2013). Effect of Compensation on Performance of Public Secondary School Teachers in Eldoret Municipality Kenya. International Journal of Scientific and Research Publications, 3(6 June), 1 -4.

Kenneth J. Meier, A. F. (2015). Employee Turnover and Organizational Performance: Testing a Hypothesis from Classical Public Administration. Published by Oxford University Press on behalf of the Journal of Public Administration Research and Theory Inc. doi:10.1093/jopart/mum028.

Malek Kristin, Shery Fried Kline, Robin DiPietro. (2018). The impact of manager training on employee turnover intentions. Journal of Hospitality and Tourism Insights, 1 (3), 203219. doi:DOI 10.1108/JHTI-02-2018-0010 Mangkunegara, A. A. (2011). "Perencanaan dan Pengembangan Sumber Daya Manusia. Bandung: PT. Refika Aditama.

Mobley., W. H. (2011). "Pergantian Karyawan: Sebab Akibat dan Pengendaliannya". Jakarta: PPM - Bisnis2030. Moekijat. (1991). Motivasi dan Pengembangan Management. Bandung: Alumni 1981.

Noe Hollenbeck, G. W. ((2015)). Human Resource Management”. 9 th. Road Maidenhead Barkshire: Mc-Graw-Hill Education Shoppenhangers .

Noe Hollenbeck., G. (2015). Human Resource Management 9 th. Road Maidenhead Barkshire SL6 2QL: Mc-Graw- Hill Education Shoppenhangers.

Potale, R. \&. ( 2015). Pengaruh Kompensasi dan Stres Kerja Terhadap Kepuasan Kerja Karyawan pada PT. Bank Sulut Cabang Utama Manado. Jurnal EMBA, 3(1), 63-73.

Priansa., D. J. ( 2014). Perencanaan \& Pengembangan SDM. Alfabeta: Bandung. 
Priyono. (2010). Manajemen Sumber Daya Manusia 2010. J1. Taman Pondok Jati J 3, Taman Sidoarjo Telp/fax : 031- 7871090, Jawa Timur: Penerbit Zifatama Publisher, Anggota IKAPI No. 149/JTI/2014 Cetakan Kedua, Mei. Diambil kembali dari Email : zifatama@gmail.com

Priyono, a. M. ( 2010). Manajemen Sumber Daya Manusia. Sidoarjo: E-Book Zifatama.

R.Dickson, Y. C. (2014). A Case Study into the Benefits of Management Training Programs: Impacts on Hotel Employee Turnover and Satisfaction Level". Journal of Human Resources in Hospitality \& Tourism, 9: 2010, 103-116. doi:10.1080/15332840903336499.ISSN: 1533-2845 print/1533-2853 online.

Rajan, D. (2017). Employee turnover and employee performance: a comparative study among nurses . MOJ Applied Bionics and Biomechanics. , 1(5):161. doi:10.15406/mojabb.2017.01.00025.

Richard L. Hughes, R. C. (2012). Leadership,Enhancing the Lessons of Experience, Alih Bahasa: Putri Izzati. Jakarta: Salemba Humanika.

Rijamampianina, R. (2015). Employee turnover rate and organizational performancein South Africabusiness. Problems and Perspectives in Management, 13(4, 2015). doi: https://orcid.org/0000-0002-4631-4801.

Rivai, V. d. (2010). Manajemen Sumber Daya Manusia untuk Perusahaan dari Teori ke Praktik. . Jakarta: PT Raja Grafindo.

Robbins., S. (2015). Perilaku Organisasi,. Jakarta.: Penerbit Salemba Empat,.

Rubel. Mohammad Rabiul Basher, D. M. (2015). High Commitment Compensation Practices and Employee Turnover Intention: Mediating Role of Job Satisfaction". Mediterranean $\begin{array}{llllll}\text { Journal of Social Sciences MCSER Publishing, } 6(6 & \text { s4). }\end{array}$ doi:10.5901/mjss.2015.v6n6s4p321

Sanaz Vatankhah, A. R. (2017). Using Compensation Satisfaction to Predict Turnover Intention and Theft among Cabin Crew: Mediating Role of Fraternal Deprivation. Journal of Service Science Research / Accepted: 09 June 2017, 08 April 2017, 9:91119. doi:DOI 10.1007/s12927-017-0006-2

Sedarmayanti. (2012). Manajemen dan Komponen Terkait Lainnya. Bandung: PT. Rafika Aditama. Wibowo. ( 2016). Manajemen Kinerja. Jakarta : PT. Rajagrafindo Persada.

Ying Cheng, F. W. (2013). Does training affect individuals' turnover intention? Evidence from China. Journal of Chinese Human Resource Management , 4( 1), 16-38. doi:10.1108/JCHRM-10-2012-0024

Youngsoo Choi and Duncan R.Dickson. (2014). A Case Study into the Benefits of Management Training Programs: Impacts on Hotel Employee Turnover and Satisfaction Level. Journal of Human Resources in Hospitality \& Tourism,, 9:103-116, 2010 Copyright CTaylor \& Francis Group, LLC. doi:”.DOI: 10.1080/15332840903336499

Yu-Li Tao, H.-L. C. (2015). Compensation and performance in Major League Baseball: Evidence from salary dispersion and team performance. doi: http://dx.doi.org/10.1016/j.iref.2015.10.0371059-0560/@2015 